\title{
Pengaruh Variasi Warna Ransum terhadap Berat Potong, Berat Karkas, Persentase Karkas dan Berat Non Karkas Ayam Broiler
}

Yunitha I. Malelak Nggi ${ }^{\mathrm{a}}$, dan Gerson F. Bira ${ }^{\mathrm{b}}$

${ }^{a}$ Fakultas Pertanian, Universitas Timor, Kefamenanu, TTU - NTT, Indonesia, email: yunithamalelak@gmail.com

${ }^{b}$ Fakultas Pertanian, Universitas Timor, Kefamenanu, TTU - NTT, Indonesia, email: gersonbira@yahoo.co.id

\section{Article Info}

Article history:

Received 7 Maret 2018

Received in revised form 10 April 2018

Accepted 19 April 2018

\section{DOI:}

https://doi.org/10.32938/ja.v3i2.426

Keywords:

Broiler

Warna Ransum

Karkas dan Non Karkas

\section{Abstrak}

Penelitian ini dilaksanakan di Kandang Percobaan milik Program Studi Peternakan pada bulan Januari sampai Februari 2018 dengan tujuan untuk mengetahui pengaruh variasi warna ransum terhadap berat potong, berat karkas, berat non karkas dan persentase karkas broiler. Rancangan yang digunakan adalah Rancangan Acak Lengkap (RAL) dengan 4 perlakuan dan 4 ulangan, yang terdiri dari $\mathrm{R}_{O}$ : ransum berwarna coklat, $R_{1}$ : ransum berwarna hijau, $R_{2}$ : ransum berwarna merah, $R_{3}$ : ransum berwarna kuning. Variabel yang di amati yakni berat potong, berat karkas, berat non karkas dan Persentase karkas. Variabel yang dilihat adalah berat potong, berat karkas, berat non karkas dan persentase karkas. Hasil analisis statistik menunjukkan variasi warna ransum berpengaruh tidak nyata $(\mathrm{P}>0,05)$ terhadap berat potong broiler. Hasil analisis statistik perlakuan penambahan warna dalam pakan ayam broiler tidak berpengaruh nyata terhadap berat karkas walaupun demikian terhadap berat karkas yang tertinggi dan terendah. Hasil analisis menunjukkan bahwa tidak ada perbedaan yang nyata warna pakan terhadap berat non karkas ayam. Hasil analisis menunjukkan bahwa persentase karkas $R_{0}$ tidak berbeda dengan $R_{1}$ dan $R_{2} \operatorname{tap}$ berbeda dengan $R_{3}$. Disimpulkan bahwa penambahan warna dalam pakan tidak dimaksudkan untuk menambah nilai nutrisi pakan namun berpengaruh terhadap sifat khas pakan itu sendiri baik secara langsung ataupun tidak langsung. Penambahan warna (coklat, merah, hijau dan kuning) dalam pakan tidak memberikan pengaruh secara nyata terhadap berat potong, berat karkas, berat non karkas dan pers entase karkas.

\section{Pendahuluan}

Meningkatnya pertambahan jumlah penduduk dan tingkat pendidikan masyarakat memberikan dampak terhadap semakin tingginya kesadaran masyarakat akan pentingnya status gizi dan kesehatan, salah satu pemenuhan gizi dan kesehatan berasal dari ternak khususnya ternak unggas. Menurut Dirjen Peternakan dan Kesehatan Hewan, (2015), konsumsi daging segar yang berasa dari unggas khususnya ayam broiler paling banyak dari jenis daging lainnya dan meningkat dalam 5 tahun terakhir ini. Dari alasan di atas maka sudah sepatutnya produksi ayam broiler perlu ditingkatkan. Dalam produksi dan pemeliharaan ayam broiler, faktor pakan merupakan salah satu faktor utama dalam menentukan tingkat keberhasilan usaha. Pakan merupakan sumber energi utama untuk pertumbuhan ternak, makin baik mutu dan jumlah pakan yang di berikan makin besar tenaga yang ditimbulkan dan masih besar pula energi yang tersimpan dalam bentuk daging.

Ayam broiler merupakan ternak yang efisien dalam mengubah bahan pakan menjadi daging yang bernilai gizi tinggi dan dapat diproduksi dalam waktu yang relatif singkat $(4-5$ minggu). Salah satu alternatif dalam meningkatkan konsumsi pakan broiler adalah penentuan warna pada ransum (Rasyaf, 2004) Selanjutnya dikatakan konsumsi ransum dapat dipengaruhi oleh kualitas dan kuantitas ransum, umur, aktivitas ternak, palatabilitas ransum, tingkat produks dan pengelolaannya. Palatabilitas ternak dapat ditingkatkan dengan perubahan fisik maupun kimiawi dari ransum yang diberikan, salah satu cara adalah pemberian warna pada ransum broiler.

Pemberian warna pada ransum berpengaruh pada bobot tubuh ternak karena selalu berbanding lurus dengan konsumsi ransum, makin tinggi bobo tubuhnya, makin tinggi pula tingkat konsumsinya terhadap ransum. Bobot tubuh ternak dapat diketahui dengan penimbangan. Keadaan selanjutnya dari konsums yang tinggi adalah perubahan kualitas dan kuantitas karkas. Bobot hidup yang semakin tinggi menyebabkan bobot karkas akan semakin tinggi begitu juga sebaliknya (Imamudin $d k k$., 2012). Karkas sering digunakan untuk menila produksi ternak khususnya produksi daging. Untuk meningkatkan kualitas karkas dan juga mengingat pentingnya memperoleh kualitas karkas broiler yang baik kembali lagi bahwa faktor pakan perlu menjadi perhatian selain faktor yang lain seperti umur potong dan lain-lain.

\section{Metode}

Penelitian ini dilaksanakan di kandang percobaan milik Program Stud Peternakan, Fakultas Pertanian Universitas Timor di Kecamatan Kota Kefamenanu, Kabupaten Timor Tengah Utara pada bulan Januari sampai Februari 2018. Penelitian berlangsung selama 1 periode produksi (45 hari). Ternak yang digunakan dalam penelitian ini adalah day old chick (DOC) jenis 707 berjumlah 80 ekor. Kandang yang digunakan adalah kandang tipe lantai yang dibuat dalam blok dan tiap blok terdiri dari 4 petak kandang berukuran 1 x 0,5 $\mathrm{m}$, tinggi dinding kandang $50 \mathrm{~cm}$ dan tinggi alas $20 \mathrm{~cm}$, timbangan duduk kapasitas $2 \mathrm{~kg}$ untuk menimbang ternak dan timbangan digital. Kandang dilengkapi dengan tempat makan dan minum, pemanas dan termometer. Pakan dibuat dari bahan-bahan lokal seperti jagung kuning, tepung ikan, tepung daun turi, dedak halus dan dibuat dalam bentuk grits (untuk ayam berumur 4 sampa 14 hari) dan bentuk pelet (untuk ayam berumur 15 sampai 45 hari). Komposis pakan dapat dilihat pada Tabel 1. dan komposisi nutrisi pada Tabel 2. Ternak ayam divaksin dengan Medival ND Literner HB1 yang diberikan dalam bentuk tetes pada mata dan vaksin ND Lasota yang di suntik pada bagian dada ternak. Variabel yang diteliti adalah berat potong sesuai petunjuk (Priyatno, 2000), bera karkas dan non karkas sesuai petunjuk Rasyaf, (2007) dan persentase karkas menurut Kartasudjana, (2001). Data yang didapat kemudian dianalisis menggunakan program SAS versi 9.1.
Tabel 1. Komposisi Bahan Pakan

\begin{tabular}{clc}
\hline No. & Bahan Pakan & Satuan $(\%)$ \\
\hline 1 & Jagung Lokal & 40,00 \\
2 & Bungkil Kelapa & 18,00 \\
3 & Tepung daun turi & 24,00 \\
4 & Tepung Ikan & 9,00 \\
5 & Dedak Halus & 7,00 \\
6 & Gaplek & 2,00 \\
\hline Total & & 100
\end{tabular}

\subsection{Pengaruh Variasi Warna Ransum terhadap Berat Potong} data berat potong diperoleh melalui penimbangan di mana sebelumnya ternak di puasakan selama 12 jam. Data hasil analisis terhadap berat potong tersaji pada Gambar 1

Tabel 2. Komposisi Nutrisi

\begin{tabular}{lccccccc}
\hline & & \multicolumn{5}{c}{ Komposisi (\%) } \\
\cline { 3 - 7 } No. & Perlakuan & Air & $\begin{array}{c}\text { Protein } \\
\text { kasar }\end{array}$ & $\begin{array}{c}\text { Lemak } \\
\text { kasar }\end{array}$ & $\begin{array}{c}\text { Serat } \\
\text { kasar }\end{array}$ & BETN & Abu \\
\hline 1. & R0 & 12,11 & 21,71 & 9,22 & 6,64 & 50,97 & 9,46 \\
2. & R1 & 12,54 & 21,70 & 8,19 & 6,13 & 50,89 & 10,09 \\
3. & R2 & 12,33 & 21,75 & 7,06 & 6,40 & 56,06 & 8,72 \\
4. & R3 & 15,13 & 21,69 & 6,78 & 5,81 & 49,72 & 11,00 \\
\hline
\end{tabular}

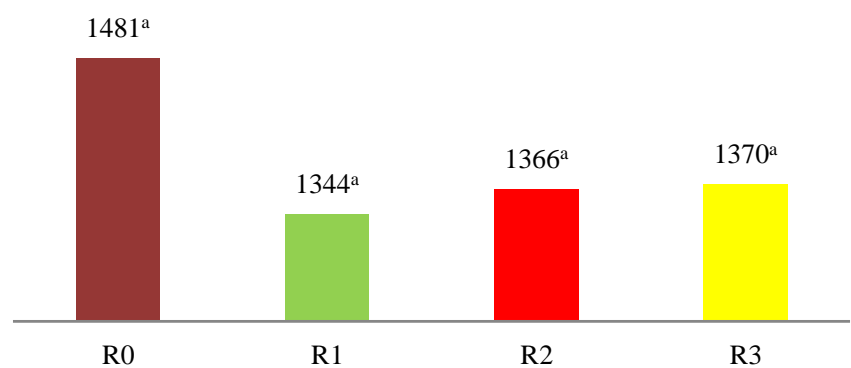

Gambar 1. Rataan berat potong broiler yang diberikan pakan dengan variasi warna yang berbeda (g/ekor/hari).

Pada Gambar 1. menunjukkan bahwa nilai rata - rata berat potong broiler pada perlakuan R0 lebih tinggi di bandingkan dengan R3, di ikuti lagi dengan R2 dan yang paling terendah adalah $\mathrm{R} 1$. Hasil analisis statistik menunjukkan varias warna ransum berpengaruh tidak nyata $(\mathrm{P}>0,05)$ terhadap berat potong broiler. Hal ini berhubungan dengan pertambahan bobot badan ayam broiler yang mendapat ransum berwarna coklat yang memang lebih tinggi di bandingkan dengan warna lain. Namun, konsumsi ransum dengan warna coklat sedikit lebih rendah apabila di bandingkan dengan warna lain, akan tetapi pertambahan bobot badan yang dihasilkan lebih tinggi dari ransum warna lainnya. Bobot potong dipengaruhi oleh pertambahan bobot badan dan umur ternak, sedangkan pertambahan bobot badan dipengaruhi oleh asupan nutrisi (Soeparno, 1994).

Secara umum bobot/berat potong yang dihasilkan dari penelitian ini masih dalam kisaran normal bahkan lebih tinggi dari hasil penelitiannya Syam, (2015) yang memberikan ayam broiler jamu probiotik lengkap dengan berat potong 1,25 $\mathrm{kg} / \mathrm{ekor}$. Hal ini disebabkan karena kandungan nutrisi serta tujuan dari pemberian

\section{Hasil dan Pembahasan}

Berat potong merupakan berat yang di peroleh pada akhir masa penelitian, 
pakan yang berbeda. Pada umumnya broiler yang siap dipanen pada usia $28-45$ hari dengan berat badan 1,2-2 kg/ekor (Priyatno, 2000).

\subsection{Pengaruh Variasi Warna Ransum terhadap Berat karkas}

Berat karkas adalah berat yang di hasilkan dari pemotongan ternak setelah di keluarkan darah, bulu, kepala, kaki dan organ-organ jeroan. Menurut Soeparno (1994), persentase karkas biasanya meningkat seiring dengan meningkatnya berat hidup, tetapi persentase bagian non karkas seperti kulit, darah, usus halus dan hati menurun. Persentase karkas ayam broiler yang mendapat ransum dengan variasi warna dapat dilihat pada Gambar 2.

Pada Gambar 2. menunjukkan bahwa nilai rata-rata berat karkas broiler pada perlakuan R0 lebih tinggi di bandingkan dengan R2 di ikuti dengan R3 dan yang paling terendah adalah $R_{1}$. Berdasarkan hasil analisis statistik perlakuan penambahan warna dalam pakan ayam broiler tidak berpengaruh nyata terhadap berat karkas walaupun demikian terdapat berat karkas yang tertinggi dan terendah. Penggunaan warna hijau dalam pakan mempunyai nilai terendah dibanding penggunaan warna lainnya. Hal ini disebabkan oleh berat potong dan pertambahan bobot badan yang memang rendah. Penurunan pertambahan bobot badan dan bobot potong akan menyebabkan berat karkas yang rendah pula (Koni, 2013). Demikian pula yang dikatakan oleh Haroen, (2003) menjelaskan pencapaian bobot karkas sangat berkaitan dengan bobot hidup dan pertambahan bobot badan.

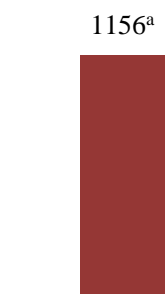

R0 $1084^{\mathrm{a}}$

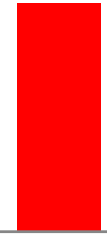

R2 $1019^{\mathrm{a}}$

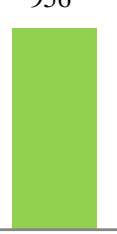

R1

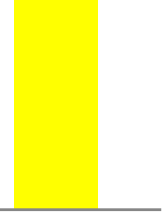

R3

Gambar 2. Rataan berat karkas broiler yang diberikan pakan dengan variasi warna yang berbeda (g/ekor).

\subsection{Pengaruh Variasi Warna Ransum terhadap Berat Non Karkas}

Gambar 3. menunjukkan bahwa pemberian ransum perlakuan R1 lebih tinggi diikuti R3 dan Ro, yang paling terendah R2. Hasil analisis menunjukkan bahwa tidak ada perbedaan yang nyata warna pakan terhadap berat non karkas ayam. Hal ini disebabkan oleh bobot potong antar perlakuan yang tidak berbeda nyata sehingga menghasilkan persentase non karkas yang hampir sama pula dan juga secara genetik ayam broiler yang sejenis akan menghasilkan pertumbuhan dan non karkas yang sama yang tidak dipengaruhi oleh pakan. Tillman $d k k$., (1991) menyatakan bahwa kecepatan pertumbuhan dari tulang kepala dan kaki, panjang badan dan otot, bagian dalam badan dan lemak terlepas dari pengaruh pakan. Hal ini diduga karena komponen kaki sebagian besar terdiri dari tulang yang pertumbuhannya pada saat dewasa adalah konstan (Dewanti $d k k$., 2013).

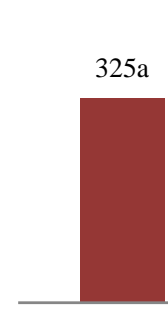

R0
$388 a$

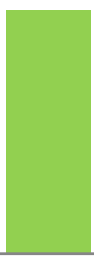

R1
$351 \mathrm{a}$

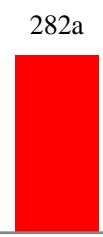

R2

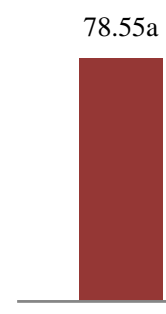

R0

$78.55 a$

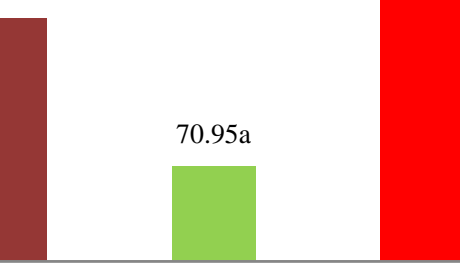

R1
$79.50 \mathrm{ab}$

R2
$74.25 b$

Gambar 4. Persentase karkas broiler yang diberikan pakan dengan variasi warna yang berbeda $(\%)$.

Rataan bobot karkas ayam broiler berkisar antara 65-75 \% dari berat hidup pada waktu siap dipotong (Murtidjo, 2003), demikian juga Resnawati (2004) yang menyatakan bahwa persentase karkas berkisar $68-71,8 \%$ dari bobot hidup. Laju pertumbuhan yang ditunjukkan dengan adanya pertambahan bobot badan akan mempengaruhi bobot potong yang dihasilkan (Dewanti $d k k$., 2013) Dilanjutkan lagi bahwa bobot potong akan berpengaruh pada persentase karkas yang dihasilkan. Hasil yang diperoleh menunjukkan tidak adanya perbedaan persentase karkas karena bobot potong yang dihasilkan juga tidak berbeda nyata.

Persentase karkas pada penelitian ini sedikit lebih tinggi, hal in kemungkinan disebabkan oleh pakan penyusun dan ransum yang diberikan. Pakan yang digunakan dalam penelitian ini disusun sedemikian rupa dari berbagai ransum dengan kandungan nutrisi yang lengkap. Imbangan protein (20$21 \%$ ) dan energi (3278 kkal/kg) dari penelitian ini merupakan imbangan yang ideal bagi pertumbuhan ayam broiler dan pada akhirnya akan meningkatkan persentase karkas, sesuai dengan standar kebutuhan yang di rekomendasikan oleh Rasyaf, (1995) bahwa pertimbangan energi metabolisme dan protein ransum ayam broiler sesuai fase umur yang digunakan dalam penelitian ini yaitu sebesar $2800-3300 \mathrm{kkal} / \mathrm{kg}$ dan protein adalah $18-22 \%$. Kandungan nutrisi pada pakan merupakan salah satu pertimbangan utama dalam pemeliharaan ayam broiler, terutama kandungan protein pada pakan. Protein merupakan kandungan nutrien pakan yang sangat mahal namun sangat dibutuhkan ayam broiler untuk pertumbuhannya yang singkat (Hakim $d k k$., 2009).

\section{Simpulan}

Penambahan warna dalam pakan tidak dimaksudkan untuk menambah nilai nutrisi pakan namun berpengaruh terhadap sifat khas pakan itu sendiri baik secara langsung ataupun tidak langsung. Penambahan warna (coklat, merah, hijau dan kuning) dalam pakan tidak memberikan pengaruh secara nyata terhadap berat potong, berat karkas, berat non karkas dan persentase karkas.

\section{Pustaka}

Bakrie B. D, Andayani, M. Yanis dan D. Zainudin. 2003. Pengaruh Penambahan Jamu Ke Dalam Air Minum Terhadap Preferensi Konsumen dan Mutu Karkas Ayam Buras. Seminar Nasional Teknologi Peternakan dan Veteriner. Puslitbang Peternakan.

Dewanti R. M. Irham dan Sudiyono. 2013. Pengaruh Penggunaan Enceng Gondok (Eichornia crassipes) Terfermentasi Dalam Ransum Terhadap Persentase Karkas, Non-Karkas, dan Lemak Abdominal Itik Lokal Jantan Umur Delapan Minggu. Buletin Peternakan Vol. 37(1) : 19-25 Februari 2013.

Direktorat Jenderal Peternakan dan Kesehatan Hewan. 2015. Statistik Peternakan dan Kesehatan Hewan. Kementerian Pertanian.

Hakim A. b. d. A. S, G. Cherian and M. N. Ali. 2009. Use of organic acid, herbs and their combination to improve the utilization of commercial low protein broiler diets. Int. J. Poultry. Sci. 8(1): 14-20.

Haroen U. 2003. Respon ayam Broiler yang diberi tepung daun sengon (Abizzania falcataria) dalam ransum terhadap pertumbuhan dan hasil karkas. Jurnal Ilmiah Ilmu-ilmu Peternakan, 6 (1): 34-41.

Imamudin A., Umiyati N. dan Nasution M. H. 2012. Pengaruh Berbagai Frekuensi Pemberian Pakan pada Pembatasan Pakan Terhadap Produksi Karkas Ayam Broiler. Animal Agricultural Journal, Vol. 1. No. 1.Fakultas Peternakan dan Pertanian, Universitas Diponegoro, Semarang.

Kartasudjana. 2001. Pengaruh Umur terhadap Persentase Karkas dan Efisiensi Ekonomis pada Ayam Broiler. Unsexed. Lembaran LPP IV.

Koni T. N. I. 2013. Pengaruh Pemanfaatan Kulit Pisang yang Difermentasi terhadap Karkas Broiler. JITV Vol. 18 No. 2 Thn. 2013; 153-157.

Murtidjo B. A. 2003. Pedoman Beternak Ayam Broiler. Kanisius: Yogyakarta.

Priyatno. 2000. Cara Beternak Ayan Broiler. Penerbit Kanisius: Yogyakarta.

Rasyaf M. 1995. Beternak Ayam Pedaging. Penerbit Penebar Swadaya. Jakarta. 2004. Pendugaan kebutuhan energi metabolis dan protein ayam broiler berdasarkan hasil pemberian makanan cara kafetaria. Disertasi. Program Pascasarjana, Institut Pertanian Bogor.

2007. Beternak Ayam Pedaging Cetakan Keempat Belas. Jakarta.

Resnawati. 2004. Efisiensi Penggunaan Protein pada Puyuh Periode Produksi yang diberi Ransum Mengandung Tepung Daun Kayambang Salvinia molesta. JIIP. 26(1):1-6. 
Soeparno C. L. 1994. Teknologi Produksi Karkas dan Daging. Cetakan ke -4 dan 5. Program Pasca Sarjana Universitas Gajah Mada: Yogyakarta.

Syam, M. 2015. Analisis Berat dan Kualitas Karkas Ayam Broiler Yang Diberikan Jamu Probiotik dan Tanaman Herbal Melalui Air Minum. Jurnal Galung Tropika, hal 74-80.

Tillman, A.D., Hartadi, H., Reksohadiprojo, S., Prowirokusumo, S. dan Lebdosoekojo, S. 1991. Ilmu Makanan ternak Dasar. Fakultas Peternakan universitas Gajah Mada, Yogyakarta. 